\title{
ANALISIS DAYA SAING FURNITURE ROTAN INDONESIA KE NEGARA TUJUAN INGGRIS DAN ITALIA
}

\author{
Muhammad Fathul Anwar'1) \\ 1)Fakultas Pertanian, Jurusan Agribisnis, Universitas Veteran Bangun Nusantara, Jl. Letjend S. \\ Humardani No 1 Jombor Sukoharjo, Telp (0271) 59315 email: fathulanwar32@gmail.com
}

\begin{abstract}
Abstrak
Furniture Rotan Indonesia merupakan salah satu komoditas alami yang telah diperdagangkan sejak lama. Sebagai salah satu kekayaan alam, furniture rotan memiliki peran penting dalam pertumbuhan ekonomi di Indoensia. Tercatat selama sebelas tahun terakhir, produk, furniture rotan merupakan komoditas utama dari ekspor Indonesia. Penelitian ini bertujuan untuk menganalisis daya saing furniture rotan Indonesia ke negara-negara pengimpor Eropa terbesarnya. Data yang digunakan dalam penelitian ini adalah data deret waktu tahunan yakni dari 2007-2016. Metode yang digunakan dalam penelitian ini yaitu melalui uji daya saing dengan pendekatan Revealed Comparative Advantage (RCA) dan Revealed Symetric Comparative Advantage (RSCA) digunakan untuk menganalisis daya saing furniture rotan Indonesia ke negara-negara importir Eropa. Hasil penelitian menunjukkan bahwa Indonesia memiliki daya saing kuat di negara pengimpor Eropa, terutama di pasar furniture rotan negara Inggris dan Italia yang memiliki daya saing lebih tinggi dibanding pasar lainnya yaitu dengan nilai RCA sebesar 141,01 dan 100,95. Hal tersebut menjadikan keduanya sebagai opsi utama pangsa ekspor furniture rotan Indonesia di masa yang akan datang.
\end{abstract}

Kata kunci: Daya saing, Ekspor, Kursi Furniture

\begin{abstract}
Indonesin rattan was one of the natural commodity which has been traded since long time ago. As one of the natural wealth, rattan furniture has important role in economic growth for Indonesia. During the past eleven years, rattan furniture is the leading commodity of Indonesia exports. This research aims to analyze the competitiveness of Indonesian rattan furniture to the largest European importing countries. The data used in this study were annual time series data from 2007-2016. The methods used were the competitiveness test with the approach of Revealed Comparative Advantage (RCA) and Revealed Symetric Comparative Advantage (RSCA) was used to analyze the competitiveness of Indonesian rattan furniture to the European importing countries. The results showed that Indonesia had strong competitiveness in European importing countries, especially United Kingdom and Italy rattan furniture market that had higher point of competitiveness with 141.01 \& 100.95 RCA's point respectively. This made both as a major export options of Indonesian rattan furniture in the future.
\end{abstract}

Keywords: Competitiveness, Export, Rattan Furniture 


\section{PENDAHULUAN}

Salah satu komoditas unggulan yang memiliki andil cukup penting bagi Indonesia adalah rotan. Olahan rotan Indonesia mampu menyumbang devisa terbesar dari hasil hutan non kayu yaitu dengan penerimaan ekspor pada tahun 2012 sebesar USD 286,72 juta, sedangkan hasil hutan non kayu lainnya yaitu minyak atsiri hanya menyumbangkan USD 222,97 juta dan hasil hutan lainnya yang sebesar USD 43,14 juta saja. Secara khusus, produk olahan berupa furniture rotan memiliki nilai ekspor cukup besar di tahun 2016-2017 masing-masing 77,38 persen dan 21,91 persen (UN Comtrade 2018).

Ekspor dari produk hasil hutan sendiri menjadi salah satu dari 10 komoditas ekspor utama di Indonesia. Sejak tahun 2012 sampai tahun 2014 ekspor produk hasil hutan menunjukan peningkatan yang sangat baik. Namun, di tahun 2014 ekspor produk hasil hutan mulai menunjukkan penurunan hingga tahun 2016. Nilai ekspor hasil hutan di tahun 2012 mencapai 8,7 Miliar US\$ dan terus meningkat hingga mencapai 9,2 Miliar US\$ di tahun 2014. Sejak tahun 2014, nilai ekspor produk hasil hutan terus menurun dan di tahun 2016 hanya mencapai 8,54 Miliar US\$.

Sebagian besarnya didominasi oleh negara-negara importir dari Eropa diantaranya adalah Jerman, Belanda, Inggris dan Italia. Keempat negara importir Eropa tersebut tergolong negara importir utama dan diantara keempatnya negara Inggris dan Italia memiliki nilai ekspor yang cukup besar diantara antara negara importir lainnya. Berikut data ekspor di tahun 2016

Merujuk pada data di tabel bawah ini, ekspor furniture rotan Indonesia ke Inggris dan Italia cukup konstan menyumbangkan devisa dalam sepuluh tahun terakhir dengan rata-rata 2.929.908 USD dan 1.956.445 USD. Sebagai salah satu negara penghasil utama furniture rotan di dunia, Indonesia memiliki peluang untuk meningkatkan ekspor furniture rotan ke pasar internasional seiring meningkatnya arus penjualan furniture di dunia. Indonesia pada dasarnya memiliki keunggulan tersendiri di bidang industri rotan yang mampu menjadikannya sebagai pemain dominan yaitu dengan ketersediaan bahan baku yang melimpah. Rotan Indonesia mempunyai posisi yang dominan di pasar dunia dimana hampir di setiap tahunnya Indonesia menyumbang sekitar $80 \%$ bahan baku rotan yang ada di dunia. Saat ini ketersediaan rotan sangat banyak dan tersebar di berbagai hutan di Indonesia terutama di wilayah Kalimantan, Sulawesi, dan Sumatera dengan jumlah produksi ratarata sebesar 690.000 ton per tahun, menjadikan Indonesia sebagai pemasok utama kebutuhan rotan dunia.

Tabel 1. Nilai Ekspor Furniture Rotan (HS 940381) Indonesia di Negara Inggris dan

\begin{tabular}{|c|c|c|}
\hline Tahun & Inggris & Italia \\
\hline 2007 & 5.776 .453 & 5.178 .323 \\
\hline 2008 & 4.407 .179 & 976.737 \\
\hline 2009 & 2.120 .127 & 884.839 \\
\hline 2010 & 5.993 .871 & 3.847 .230 \\
\hline 2011 & 2.662 .530 & 2.043 .939 \\
\hline 2012 & 1.441 .210 & 2.091 .648 \\
\hline 2013 & 1.710 .022 & 1.601 .800 \\
\hline 2014 & 1.592 .709 & 1.260 .067 \\
\hline 2015 & 1.974 .448 & 897.196 \\
\hline 2016 & 1.620 .532 & 782.673 \\
\hline Rata-rata & 2.929 .908 & 1.956 .445 \\
\hline
\end{tabular}

Sumber: UNCOMTRADE (2018)

Di sisi lain, persaingan pasar global yang semakin kompetitif baik dari kualitas maupun kuantitas produk menjadi ancaman bagi perdagangan Indonesia di pasar internasional (Ciffolilli dan Muscio 2018). Oleh karena itu, dibutuhkan usaha yang lebih komprehensif dan terintegrasi untuk meningkatkan pangsa pasar Indonesia. Produk furniture rotan Indonesia harus memiliki daya saing yang kuat di pasar internasional. Negara yang mempunyai daya 
Agrisaintifika

Jurnal Ilmu-Ilmu Pertanian

Vol. 5, No. 1, 2021

Anwar, M. Fathul. 2021

saing tinggi akan memiliki kemampuan untuk bertahan bahkan menguasai pasar dunia. Laursen (2015) menyatakan bahwa persaingan negara di pasar global semakin ketat dikarenakan beberapa negara memproduksi produk yang sama dengan kualitas yang lebih baik.

Kondisi perdagangan bebas menjadikan pasar internasional dikuasai oleh negara yang memilki daya saing (Peneder dan Streicher 2018) sehingga dibutuhkan usaha yang lebih komprehensif dan terintegrasi untuk meningkatkan pangsa pasar furniture rotan Indonesia. Hal tersebut menjadikan furniture rotan menjadi salah satu sektor industri unggulan dibanding dengan komkoditi lain yang memiliki sektor industri sama di Indonesia. Oleh karena itu perlu adanya suatu analisa untuk mengetahui sejauh mana tingkat daya saing ekspor dari industri furniture rotan Indonesia ke negara ekspor utama Inggris dan Italia, guna mendukung peningkatan daya saing industri furniture rotan Indoensia di masa yang bakan datang.

\section{BAHAN DAN METODE}

Penelitian ini merupakan penelitian deskriptif dengan menggunakan data sekunder. Data yang dianalisis berupa nilai ekspor furniture rotan dengan kode HS 940381 di negara eksportir utama Inggris dan Italia dari tahun 2007 sampai 2016. Rentang data tahun yang digunakan tersebut, merupakan data terakhir dari HS 940381 mengingat di tahun setelahnya komoditi HS 940381 telah berganti menjadi lebih spesifik lagi. Negara yang menjadi objek penelitian dipilih berdasarkan rata-rata nilai ekspor tertinggi selama 10 tahun terakhir dan berfokus di wilayah Eropa. Adapun negara eksportir Eropa utamanya yaitu Inggris dan Italia. Metode kuantitatif yang digunakan adalah metode Revealed Comparative Advantages (RCA) yaitu untuk menganalisis daya saing furniture rotan Indonesia.

\section{Revealed Comparative Advantage (RCA)}

RCA yang dikemukakan oleh Balassa (1965) merupakan salah satu alat ukur untuk menentukan tingkat kemampuan daya saing komoditas tertentu di pasar internasional. Rasio RCA ini akan digunakan dalam melakukan analisis perdagangan internasional untuk menentukan posisi ekspor produk tertentu suatu negara terhadap produk tertentu dari negara lainnya (Laursen 2015).

Menurut Basri dan Munandar (2010), RCA merupakan salah satu metode yang dinamis dan mampu digunakan untuk melakukan analsis daya saing. Penelitian ini menggunakan metode RCA untuk analisis daya saing seperti halnya digunakan pada beberapa penelitian komoditas perkebunan dan hasil hutan lainnya seperti kopi (Boansi et al. 2013), kakao (Rifin 2013; Firdaus 2009), rotan (Hoang et al. 2017). Menurut Serin dan Civan (2008), RCA (Revealed Comparative Advantages) yang dikemukakan oleh Balassa (1965) merupakan salah satu alat ukur untuk menentukan tingkat kemampuan daya saing komoditas tertentu di pasar internasional. Rasio RCA ini akan digunakan dalam melakukan analisis perdagangan internasional untuk menentukan posisi ekspor produk tertentu suatu negara terhadap produk tertentu dari negara lainnya (Laursen 2015).

Secara matematis, RCA dapat dihitung menggunakan rumus seperti pada rumus (1) dimana variabel yang diukur pada metode ini meliputi kinerja ekspor suatu produk pada wilayah terhadap total ekspor wilayah tersebut yang kemudian dibandingkan dengan pangsa nilai produk dalam perdagangan dunia. Rumus dari RCA dapat dilihat pada persamaan berikut (Balassa \& Noland 1989) :

$R C A=\frac{X_{i j} / X_{i t}}{W_{i} / W_{t}}$

dimana:

RCAi : Nilai daya saing furniture rotan Indoensia ke negara Inggris dan Italia

Xij : Nilai ekspor furniture rotan Indoensia ke ke negara Inggris dan Italia 
Xit : Nilai ekspor total semua komoditas Indonesia ke negara Inggris dan Italia

Wi : Nilai ekspor furniture rotan seluruh Dunia ke negara Inggris dan Italia

$\mathrm{Wt}$

: Nilai ekspor total semua komoditas

Dunia ke negara Inggris dan Italia

(Balassa 1965)

Dalam analisis yang lebih rinci, Indeks RCA Balassa dapat diklasifikasikan ke dalam empat tahap (Hinloopen 2001) :

1. Nilai $R C A, 0<R C A<1$, menunjukkan bahwa negara $\mathrm{j}$ tidak memiliki keunggulan komparatif (no competitiveness).

2. Nilai $R C A, 1<R C A<2$, menunjukkan bahwa negara j memiliki keunggulan komparatif akan tetapi masih lemah (week competitiveness).

3. Nilai $R C A, 2<R C A<4$, menunjukkan bahwa negara j memiliki keunggulan komparatif yang sedang (moderate competitiveness).

4. Nilai RCA > 4, menunjukkan bahwa negara j memiliki keunggulan komparatif yang kuat (strong competitiveness).

\section{Revealed Symetric Comparative Advantage (RSCA)}

Penentuan tingkat daya saing menggunakan RCA juga memiliki kekurangan yang disebabkan karena hasil indeks yang tidak simetris (Laursen 1998). Dalam penggunaannya, RCA juga tidak terlalu dapat menjelaskan apakah suatu pola perdagangan yang sedang terjadi sudah optimal atau belum. Penentuan tingkat daya saing menggunakan RCA juga memiliki kekurangan lain yakni hasil indeks yang diciptakan terkadang masih kurang simetris, dimana output yang dihasilkan analisis RCA tidak dapat dibandingkan pada kedua sisinya. Maka dilakukan modivikasi RCA atau indeks Balassa oleh Dalum dalam Oktaviani et al. (2014) yang dikenal dengan Revealed Symetric Comparative Advantage (RSCA). Range pengukuran RSCA berkisar antara -1 hingga 1 dan secara umum dirumuskan sebagai berikut:
$R S C A j=\frac{R C A_{t}-1}{R C A_{t}+1}$

dimana:

$\mathrm{RCA}_{\mathrm{t}} \quad$ : Nilai daya saing furniture rotan Indoensia ke negara tujuan Inggris \& Italia)

RSCAj : Nilai RSCA suatu Negara

t $\quad: \quad 2007, \ldots 2016$

(Dalum et al. 1998)

Dimana RSCAj, adalah RSCA ekspor komoditas furniture rotan Indonesia tiap negara importir eropa. Nilai RSCA berkisar antara -1 hingga 1. Ketika nilai RSCA diatas nol (bernilai positif), artinya negara tersebut memiliki keunggulan komparatif untuk produk furniture rotan di negara tujuan utama. Sebaliknya jika RSCA bernilai negatif, maka negara tersebut tidak memiliki keunggulan komparatif komoditas furniture rotan.

\section{HASIL DAN PEMBAHASAN}

Kinerja ekspor furniture rotan Indonesia di pasar internasional dapat dilihat dari keunggulan komparatifnya dengan metode RCA. RCA mengukur pangsa pasar ekspor suatu negara dalam kelompok sektor industri yang sama dengan negara eksportir lainnya.

Berdasarkan Tabel 2, Indonesia sebagai salah satu produsen dan pengekspor furniture rotan, memiliki keunggulan komparatif yang cukup besar. Berdasarkan hasil analisis RCA dapat diketahui bahwa komoditi furniture rotan Indonesia memiliki keunggulan komparatif di pasar Inggris dan Italia dengan perolehan nilai rata-rata $\mathrm{RCA}$ lebih dari satu $(R C A>1)$ selama periode tahun 2007-2016. Apabila diperhatikan pada Tabel 2. dalam periode tahun 2007-2016, terlihat bahwa rasio RCA untuk komoditi furniture rotan Indonesia di Inggris dan Italia memiliki nilai di atas 1. Hal ini memiliki artian bahwa komoditas furniture rotan Indonesia 
mempunyai keunggulan komparatif di negara tujuan ekspor utama dibanding dengan daya saing untuk jenis komoditas yang sama. Nilai RCA rata-rata Indonesia selama 10 tahun (2007-2016) yakni sebesar 141,01 untuk eskpor di negara Inggris dan 100,95 untuk ekspor di negara Italia. $\mathrm{Di}$ pasar internasional, Indonesia merupakan eksportir furniture rotan terbesar ke-tiga bersaing dengan eksportir lain yakni China dan Jerman.

Tabel 2. Nilai RCA Furniture Rotan (HS 940381) Indonesia di Negara Inggris dan Italia tahun 2007-2016

\begin{tabular}{|c|c|c|}
\hline Tahun & UK & Italia \\
\hline 2007 & 204,33 & 168,04 \\
\hline 2008 & 207,50 & 33,37 \\
\hline 2009 & 114,07 & 36,12 \\
\hline 2010 & 182,74 & 123,47 \\
\hline 2011 & 186,40 & 108,56 \\
\hline 2012 & 118,97 & 104,78 \\
\hline 2013 & 117,09 & 146,12 \\
\hline 2014 & 88,46 & 128,03 \\
\hline 2015 & 114,95 & 109,62 \\
\hline 2016 & 75,57 & 51,38 \\
\hline Rata-rata & 141,01 & 100,95 \\
\hline
\end{tabular}

Terlihat dari nilai RCA pada Tabel 2. kekuatan daya saing industri furniture rotan Indonesia mengalami pertumbuhan yang cukup fluktuatif dari tahun 2007-2016. Terkait perkembangan daya saing di tiap negara tujuannya, Inggris menjadi negara tujuan ekspor furniture rotan Indonesia dengan nilai daya saing tertinggi dan cukup mendominasi dibandingkan dengan negara Italia, dimana di setiap tahunnya ekspor di negara Inggris rata-rata memiliki nilai $R C A$ sebesar 141,01 sedang Italia dengan 100,95 . Periode nilai RCA terbesar dari Inggris terjadi di tahun 2007 dan 2008, dimana berturut-turut nilai RCA mampu menembus di angka 204,33 dan 207,50 . Nilai tersebut merupakan nilai tertinggi juga untuk komoditas furniture rotan Indonesia di sepanjang periode di antara tiap negara tujuan.

Italia menjadi dua negara tujuan ekspor terbesar setelah Inggris, dimana per tahunnya nilai RCA di Italia menyentuh angka 100,95 . Nilai RCA di Italia sendiri secara keseluruhan juga mengalami fluktuasi di sepanjang periode 2007-2016. Fluktuasi yang terjadi di kedua negara tersebut pada dasarnya lebih disebabkan oleh adanya penerapan kebijakan tarif di Uni Eropa terkait impor produk furniture yang mana salah satunya adalah produk mentah dan juga hasil jadi rotan di pada tahun 2008 dengan besaran $0,056 \%$. Tarif yang ada menjadi salah satu penghalang bagi para importir lokal disana untuk terus melakukan impor komoditi furniture rotan Indonesia dengan skala yang sama dari tahun sebelumnya. Tercatat negara-negara Eropa yang sebagian besar sebagai negara tujuan ekspor utama telah menerapkan tarif impor sebesar 0,056\% untuk produk furniture rotan (UNCTAD 2018). Adanya tarif tersebut mau tidak mau menjadikan produk furniture rotan menjadi lebih mahal dari segi biaya yang berdampak pada pasar ekspor yang menjadi tidak terlalu stabil. Selain itu fluktuasi yang terjadi juga dipengaruhi oleh kebijakan pemerintah Indonesia terkait buka tutupnya bahan baku rotan mentah yang masih sering berubah di periode tersebut yang menjadikan lesunya produksi di industri furniture rotan Indonesia. Secara keseluruhan Indonesia masih memiliki besaran nilai yang cukup kuat dan tergolong berdaya saing dalam hal komoditas furniture rotan, dengan niilai RCA yang telah menunjukkan keunggulan komparatif ekspor furniture rotan Indonesia di masing-masing negara eksportir utama. Hasil ini cukup sejalan dengan penelitian yang sebelumnya pernah dilakukan oleh Kismandani (2008), dimana furniture rotan telah menunjukkan daya saing yang kuat sebagai salah satu komoditas ekspor Indonesia dan dapat 
Agrisaintifika

Jurnal Ilmu-Ilmu Pertanian

Vol. 5, No. 1, 2021

Anwar, M. Fathul. 2021

dikatakan masih berdaya saing di pasar internasional.

Tabel 3. Nilai RSCA Furniture Rotan (HS 940381) Indonesia di Negara Inggris dan Italia tahun 2007-2016

\begin{tabular}{|c|c|l|}
\hline Tahun & UK & Italia \\
\hline 2007 & 0,99 & 0,99 \\
\hline 2008 & 0,99 & 0,94 \\
\hline 2009 & 0,98 & 0,95 \\
\hline 2010 & 0,99 & 0,98 \\
\hline 2011 & 0,99 & 0,98 \\
\hline 2012 & 0,98 & 0,98 \\
\hline 2013 & 0,98 & 0,99 \\
\hline 2014 & 0,98 & 0,98 \\
\hline 2015 & 0,98 & 0,98 \\
\hline 2016 & 0,97 & 0,96 \\
\hline Rata-rata & 0,98 & 0,97 \\
\hline
\end{tabular}

Berdasarkan hasil analisis RSCA seperti yang terlihat pada Tabel 3. dapat diketahui bahwa komoditi furniture rotan Indonesia memiliki keunggulan komparatif yang kuat dan juga stabil di pasar Inggris dan Italia dengan perolehan nilai rata-rata Indeks RSCA diatas nol (bernilai positif) selama periode tahun 2007-2016. Dalam perkembangannya nilai indeks RSCA furniture rotan Indonesia terus mengalami perkembangan yang cukup stabil dan konstan di tiap tahunnya. Hal tersebut terlihat dari nilai yang ada yakni hampir di setiap tahunnya nilai RSCA stabil dan konstan mendekati angka satu. Terkait perkembangannya, Inggris menjadi negara tujuan ekspor furniture rotan Indonesia dengan nilai RSCA yang paling stabil dibanding dengan negara Italia, dimana di setiap tahunnya di negara Inggris rata-rata memiliki nilai RSCA sebesar 0,98. Hampir di setiap tahunnya Inggris menunjukkan kestabilan nilai tersebut, yakni tidak jauh dari kisaran 0,98 ke 0,99. Hal yang tidak jauh berbeda sebenarnya juga terjadi pada Italia dimana nilai Italia secara kondtan juga

berkisar diantara 0,976 ke 0,99 dengan rataan berkisar 0,97. Kestabilan tersebut secara tidak langsung memperlihatkan bahwa pasar ekspor furniture rotan Indonesia di Inggris telah memiliki dominasi daya saing yang cukup kuat, dan konsisten terbukti dengan adanya permintaan furniture rotan Indonesia di negara tersebut yang tiap tahunnya cukup besar meskipun di eropa telah ditetapkan tarif impor untuk komoditi tersebut. Italia menjadi negara kedua terbaik dalam hal perkembangan nilai RSCA, dimana secara garis besar nilai yang ada di italia dalam periode 2007-2016 cukup berkembang dan stabil seperti di negara Inggris. Hal yang cukup membedakan adalah di periode awal justru nilai RSCA di Italia sangat drastis menurun, yakni terjadi di periode 2008 dengan hanya 0,94 yang menurun dari nilai sebelumnya 0,99 .

Kinerja daya saing furniture rotan Indonesia di Italia kembali membaik di tahun 2009, dimana hal tersebut ditunjukkan dengan meningkatnya nilai RSCA yang ada menjadi 0,95 di 2009 kemudian terus membaik di periode selanjutnya dengan nilai 0,98 dan mencapai puncaknya di 2013 sebesar 0,99. Setelah itu besaran nilai RSCA yang ada di Italia lebih cenderung stabil dan bersaing dengan besaran yang mirip dengan negara Inggris. Kestabilan nilai yang ada di Inggris dan Italia menjadi salah satu bentuk gambaran pasti dalam pemetaan daya saing di pasar komoditi furniture rotan Indonesia. Tren kestabilan ini seharusnya dapat menjadi acuan tersendiri bagi Indonesia untuk lebih memberikan prioritas bagi perkembangan ekspor furniture rotan ke negara tersebut guna menunjang perkembangan daya saing furniture rotan di masa mendatang.

Berbeda halnya dengan Inggris dan Italia, negara eropa lain yang juga melakukan impor furniture rotan dari Indonesia seperti Jerman dan Belanda cukup mengalami fluktuasi nilai yang signifikan. Dari data UNCOMTRADE tercatat Jerman pada 
awalnya terlihat menunjukkan perkembangan yang stabil dan hampir mirip dengan Inggris, akan tetapi di periode 2012 Jerman mulai menunjukkan tren buruk nilai RSCA nya. Hal yang tak tidak jauh berbeda terjadi juga dengan perkembangan nilai Belanda, dimana Belanda tercatat memiliki nilai RSCA dengan gambaran yang kurang stabil dan cenderung cukup fluktuatif. Dalam rentang periode 20072016 fluktuasi yang terjadi di Belanda cukup terlihat dari besarnya nilai RSCA yang berubah-ubah. Fluktuasi nilai RSCA yang ada secara garis besar memang mayoritas terjadi di negara-negara tujuan di Eropa dan tak berbeda jauh bedanya dengan fluktuasi yang terjadi pada nilai RCA. Hal tersebut cukup menunjukkan ketidakkonsistenan dari kinerja ekspor dan juga daya saing dari komoditi furniture rotan Indonesia yang memang dipengaruhi oleh adanya penerapan kebijakan tarif di Uni Eropa terkait impor produk furniture, yang mana salah satunya adalah tarif produk mentah dan juga hasil jadi rotan di pada tahun 2008 dengan besaran 0,056\% (UNCTAD 2018). Selain dikarenakan tarif impor tersebut, krisis ekonomi dunia di periode tahun 2008-2010 juga menjadi salah satu faktor yang menyebabkan fluktuasi nilai tersebut. Nilai tukar Rupiah yang terpengaruh oleh mata uang asing negara ekspor selalu berubah dari waktu ke waktu dan cukup memberi dampak pada setiap perubahan yang terjadi. Perubahan nilai mata uang tersebut berhubungan dengan keputusan pelaku kegiatan perdagangan.

Peningkatan maupun penurunan kurs mata uang sangat mempengaruhi keputusan pelaku eskpor furniture rotan Indonesia untuk menjual produknya. Perbedaan nilai tukar mata uang suatu negara pada prinsipnya ditentukan oleh besarnya permintaan dan penawaran mata uang tersebut. Kurs merupakan salah satu harga yang penting dalam perekonomian terbuka karena ditentukan oleh adanya keseimbangan permintaan dan penawaran yang terjadi di pasar. Kurs juga dapat dijadikan alat ukur untuk mengukur kondisi perekonomian suatu negara. Pertumbuhan nilai mata uang yang stabil menunjukan perekonomian suatu negara memiliki kondisi ekonomi yang relatif baik. Melemahnya nilai tukar Rupiah menyebabkan perekonomian Indonesia menjadi tidak stabil dan dilanda krisis ekonomi serta kepercayaan terhadap mata uang dalam negeri menurun. Ketika krisis terjadi, ekonomi Indonesia akan terpengaruhi. Hal tersebut langsung berdampak pada pelemahan mata uang Rupiah terhadap nilai tukar mata uang asing negara ekspor dan menyebabkan ketidakstabilan pada nilai tersebut. Tidak stabilnya nilai kurs Rupiah terhadap nilai tukar mata uang asing negara tujuan menyebabkan nilai ekspor furniture rotan Indonesia turut berfluktuasi sehingga mempengaruhi kinerja ekspor dan daya saing furniture rotan Indonesia itu sendiri.

\section{SIMPULAN Kesimpulan}

Hasil penelitian menunjukkan bahwa dalam kurun waktu 2007-2016, ekspor komoditi furniture rotan Indonesia memiliki daya saing yang kuat di pasar internasional, terutama di negara Inggris dan Italia. Daya saing furniture rotan Indonesia baik di negara Inggris dan Italia memiliki trend yang meningkat dan stabil dalam kurun waktu 11 tahun. Nilai RCA menunjukkan keunggulan komparatif ekspor furniture rotan Indonesia di masing-masing negara importir utama, dimana negara tujuan dengan besaran keunggulan komparatif tertinggi berada di pangsa Inggris diikuti dengan Italia. Berdasarkan nilai RSCA juga diperoleh kesimpulan yang cukup sama, dimana nilai RSCA Indonesia untuk pasar furniture rotan di pasar negara Inggris merupakan nilai RSCA yang paling mendekati 1 jika dibandingkan dengan negara tujuan lainnya. Negara tujuan Inggris secara garis besar memiliki nilai rata-rata RCA dan RSCA yang mengindikasikan posisi daya saing yang 
paling kuat diantara negara eksportir lainnya, namun jika diperhatikan lebih lanjut, selain pasar utama Inggris, posisi daya saing yang kuat juga dimiliki oleh Italia dan Jerman yang menjadikan keduanya sebagai pasar ekspor lainnya yang dapat dijadikan opsi utama pangsa ekspor lain dalam hal ekspor furniture rotan Indonesia.

\section{Saran}

Berdasarkan hasil penelitian yang dilakukan, dapat disampaikan saran bagi pemerintah. Adapun usaha yang perlu dilakukan yaitu perlunya usaha dalam meningkatan furniture rotan Indonesia. Peningkatan daya saing tersebut dapat dilakukan dengan meningkatkan kualitas dan standar produk. Disamping itu, Kekonsistenan dari Pemerintah dalam menerapkan pembatasan ekspor bahan baku sangatlah diperlukan, hal tersebut dapat dilakukan melalui suatu skema pengawasan. Adanya suatu badan penyangga diharapkan dapat berfungsi sebagai stabilisator ketersediaan bahan baku bagi industri furniture rotan di Indonesia baik dari segi kuantitas, kualitas maupun harga.

\section{DAFTAR PUSTAKA}

Balassa B. 1965. Trade liberalization and revealed comparative advantage. The Manchaster School of Economic and Sosial Studies. 33: 92-123.

Balassa B, Noland M. 1989. Revealed Comparative Advantage in Japan and the United States. Journal of International Economic Integration. 4(2): 8-22.

Basri F, Haris M. 2010. Dasar-Dasar Ekonomi Internasional: Pengenalan \& Aplikasi Metode Kuantitatif. Jakarta (ID): Kencana.

Boansi, David dan Crentsil, Christian. 2013. Competitiveness and Determinants of Coffee Exports, Producer Price and
Production for Ethiopia. Journal of Advanced Research in Economics and International Business Vol. 1, Issue 1(1)

Boansi D, Odilon K, Lokonon B, Appah J. 2014. Determinants of agriculturl export trade: case of fresh pineapple exports from Ghana. British journal of economics, management \& trade. 4(11):1736-1754.

Firdaus M. 2007. Analisis Daya Saing Kedelai di Jawa Timur. J-SEP. 1 (2): 1627.

Ciffolilli A, Muscio A. 2018. Industry 4.0: National and Regional Comparative Advantages in Key Enabling Technologies. European Planning Studies, 26(12): 2323-2343.

Gujarati D. 2006. Dasar-Dasar Ekonometrika. Mulyadi, J, A; Penerjemah; Saat, S; Hardani, W; Editor. Jakarta (ID): Erlangga. Terjemahan dari:Essentials of Economics.

Hinloopen J. 2001. On the empirical distribution of the Balassa Index. Review of World Economics. 137 (1): 1-49.

Hoang V, Tran T, Tu V, Nguyen N, Nguyen Q. 2017. Agricultural Competitiveness of Vietnam by the RCA and the NRCA Indices, and Consistency of Competitiveness Indice. AGRIS on-line Papers in Economics and Informatics. 9 (4): 53-67.

[KEMENPERIN] Kementerian Perindustrian. 2017. Perkembangan Ekspor Indonesia Berdasarkan Sektor. Jakarta (ID): Kementerian Perindustrian Republik Indonesia.

Laursen K. 2015. Revealed comparative advantage and the alternatives as measures of international specialization. Eurasia Business and Economics Society. 5: 99-115.

Oktaviani R, Novianti T. 2014. Teori Perdagangan Internasional; Aplikasinya di Indonesia. Bogor (ID): IPB Press. 
Agrisaintifika

Anwar, M. Fathul. 2021

Peneder M, Streicher G. 2018. Deindustrialization and comparative advantage in the global value chain. Economic Systems Research. 30(1): 85104.

Seyoum B. 2007. "Revealed comparative advantage and competitiveness in services: A study with special emphasis on developing countries". Journal of Economic Studies. Vol. 34 Iss. 5 : 376 388

Serin V dan Civan A. 2008. Revealed Comparative Advantage and
Competitiveness : A Case Study for Turkey Towards the EU. Journal of Economics and Social Research 10(2) : 25-41.

Suprihatini, R. 2005. Daya Saing Ekspor The Indonesia di Pasar Dunia. Jurnal Agro Ekonomi, Vol. 23 No. 1: 1-29.

UNCTAD. 2018. Tariff Measures to Trade: Economic and Policy Issues for Developing Countries. Switzerland. Geneva.

World Bank. 2018. Pink sheet data World Bank. Washington DC: World Bank. 